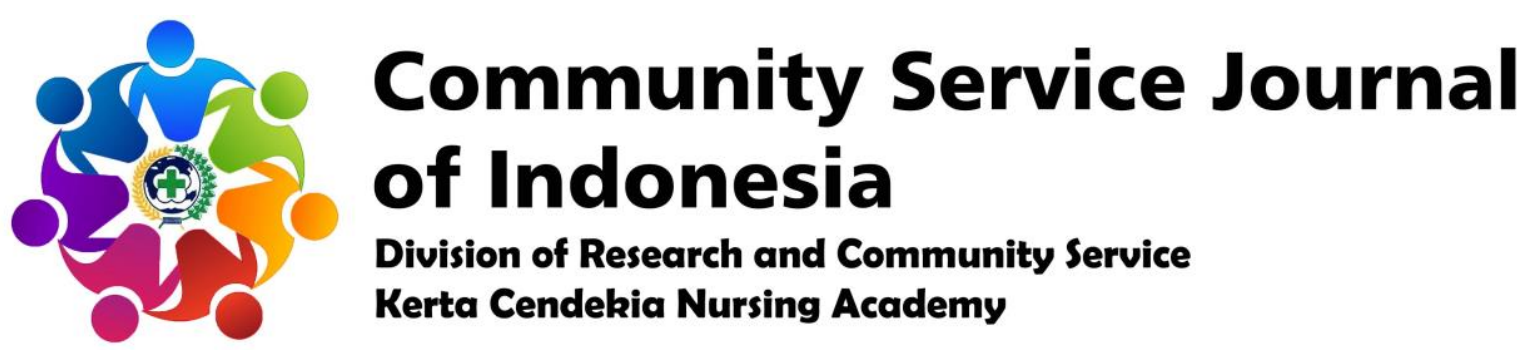

https://ejournal-kertacendekia.id/index.php/csji/index

Community Service Journal of Indonesia 2 (2) (2020): 28-35

Doi: https://doi.org/10.36720/csji.v2i2.253

\title{
TRANSMISSION-BASED PRECAUTION EDUCATION ON KNOWLEDGE AND HANDWASHING PRACTICES IN SCHOOL-AGED CHILDREN IN THE ERA OF PANDEMI COVID-19
}

\author{
Lingga Curnia Dewi ${ }^{1 *}$, Ika Nur Pratiwi ${ }^{1}$, Rr. Dian Tristiana ${ }^{1}$ \\ ${ }^{1}$ Faculty of Nursing, Airlangga University, Surabaya, Indonesia \\ * Correspondence \\ Lingga Curnia Dewi \\ Faculty of Nursing, Airlangga University, Surabaya, Indonesia \\ Kampus C, Jl. Mulyorejo, Mulyorejo, Surabaya City, East Java Province - 60115 \\ Email: lingga.curnia@fkp.unair.ac.id
}

\begin{abstract}
Washing hands is important to prevent various infectious diseases, including Covid-19. School-age children are a population at risk who must practice proper hand hygiene. This study aims to examine the effect of Transmission-Based Precaution (TBP) on knowledge and practice of hand washing in school age children. A total of 20 schoolchildren living in Islamic boarding schools participated in this study. Education is carried out in one meeting. The data was collected by filling out a questionnaire on knowledge and hand washing practices pre and post education. The results showed that providing TPB education increased knowledge about hand washing $(p=$ $0.010)$, but it was not significant for hand washing practices $(p=0.282)$. Increasing knowledge should also pay attention to the attitude of school children in hand washing behavior. The process of providing education will be more embedded in school children after repeatedly implementing hand washing properly. The teachers and classmates involved can participate in hygiene education to encourage the hand washing behavior of students in areas at high risk of infectious diseases, especially Covid-19.
\end{abstract}

Keywords: Washing hand, transmission-based precaution, school-aged children, health education.

(C) 2020 The Authors. Community Service Journal of Indonesia Published by Community Service and Research of Kerta

Cendekia Nursing Academy - Kerta Cendekia Nursing Academy

This is an Open Access Article distributed under the terms of the Creative Commons Attribution 4.0 International License

which permits unrestricted non-commercial use, distribution, and reproduction in any medium, provided the original work is

properly cited.

E-ISSN

2684-7884 


\section{INTRODUCTION}

Covid-19 is an infectious disease that continues to spread throughout the world, including Indonesia (Hirai, et al., 2016). SARS-Cov-2 is highly contagious through droplets, air and direct contact with the infected environment (Kratzel, et al., 2020). Transmission-Based Precaution (TBP) is an important measure in preventing virus transmission in the community (Mahmud, et al., 2015). One of the important recommendations from the TPB's actions in the era of the COVID-19 pandemic by the WHO (World Health Organization) is to wash hands properly. Washing hands makes a significant contribution to reducing the direct spread of the coronavirus. In addition, frequent hand washing with running water and soap or alcohol can eliminate pathogens and deactivate SARS-CoV-2 (Centers for Disease Control and Prevention [CDC], 2002).

School children living in risky areas may have poor hand hygiene habits and may be susceptible to disease, especially Covid-19 (Haas, 2016). Although hand washing is a simple and efficient method to reduce the risk of infectious diseases, the results of previous studies have shown relatively low levels of adherence to washing hands in the recommended and correct manner (Contzen and Mosler, 2015). Most of the santri children living at the Rodhiyatul Jannah Islamic Boarding School, Surabaya, East Java still do not pay attention to the issue of hand hygiene, especially hand washing. One of the reasons for this is the lack of knowledge on the importance of maintaining hand hygiene and how to wash hands properly according to WHO recommendations.

Health education is a planned or planned contribution starting from learning experiences based on theory and delivered to individuals, groups and communities with the aim of increasing their capacity or capacity and competence in making health decisions. Therefore, health education about proper hand washing is expected to be a relevant contribution to breaking the cycle of transmission of various infections (Chittleborough, et al., 2012).

Previous literature studies describing health education from hand washing in school-age children during the Covid-19 pandemic are still very limited, because most of the existing literature still focuses on health care professionals such as doctors, nurses, and other health professionals (Dickie, et al., 2018). This study aims to determine the effect of TBP education on the level of knowledge and practice of hand washing in school age children.

\section{OBJECTIVES}

General Purpose

After carrying out this health education activity, it is hoped that the respondent will be able to know about proper hand washing and practice it well.

\section{Special Purpose}

Following up on the general objectives of the implementation of this health education activity, the specific objectives of this activity are as follows:

1. Increased knowledge about proper hand washing.

2. Able to practice proper and proper hand washing.

\section{PLAN OF ACTION}

Strategy Plan

Before this extension activity was carried out, there were several things that were carried out by the implementing team 
of this activity. Some of these things are contained in the strategy for implementing outreach activities, including:

1. Conduct coordination meetings between members of the activity implementing team.

2. Conduct site surveys to capture the needs of implementation and counseling on target.

3. Prepare facilities and infrastructure that will be used in the implementation of extension activities.

\section{Implementation}

At the time of its implementation, several health education activities on hand washing were carried out, including:

1. The implementation of giving materials related to knowledge of proper hand washing procedures, demonstrating proper hand washing procedures.

2. The evaluation of the material is carried out using a questionnaire that has been prepared previously. The questionnaire consisted of demographic data, knowledge and hand washing practices. There are 6 questions related to knowledge about Covid-19 and washing hands and 20 questions about the practice of washing hands. The data were then analyzed statistically using SPSS.

\section{Setting}

This counseling activity was carried out at the Rhodiyatul Jannah Islamic Boarding School, Surabaya, East Java Province. With the target of the activity is 20 school children who are students who live in the Islamic boarding school. The activity was held in September 2020.

\section{Target}

The target of this health education activity is 20 school children who are students living in the Rodhiyatul Jannah Islamic Boarding School, Surabaya, East Java Province.

\section{RESULTS AND DISCUSSION}

Based on the results of the evaluation carried out by the health education activity implementation team, some data was obtained, including:

Table 1. Demographics of respondents to health education activities about washing hands based on the TBP method at the Rodhiyatul Jannah Islamic Boarding School, Surabaya, East Java Province in September $2020(n=20)$.

\begin{tabular}{lccc}
\hline \multicolumn{1}{c}{ Characteristics of respondents } & $\mathbf{n}$ & $\mathbf{\%}$ & mean \\
\hline Gender & & & \\
$\quad$ Male & 14 & 70 & \\
$\quad$ Female & 6 & 30 & \\
Age & & & 12,65 \\
Money per months & 15 & 75 & \\
$\quad<500.000$ rupiahs & 0 & 0 & \\
$\quad>500.000-1.500 .000$ rupiahs & 2 & 10 & \\
$\quad>1.500 .000-2.000 .000$ rupiahs & 3 & 15 & \\
$\quad>2.000 .000-2.500 .000$ rupiahs & &
\end{tabular}




\begin{tabular}{cccc}
\hline Characteristics of respondents & n & \% & mean \\
\hline Level of Educational & 12 & 60 & \\
Elementary school & 3 & 15 & \\
Junior High School & 5 & 25 & \\
Senior High School &
\end{tabular}

Table 2. Distribution of handwashing knowledge questionnaire results based on the TBP method at the Rodhiyatul Jannah Islamic Boarding School, Surabaya, East Java Province in September $2020(n=20)$.

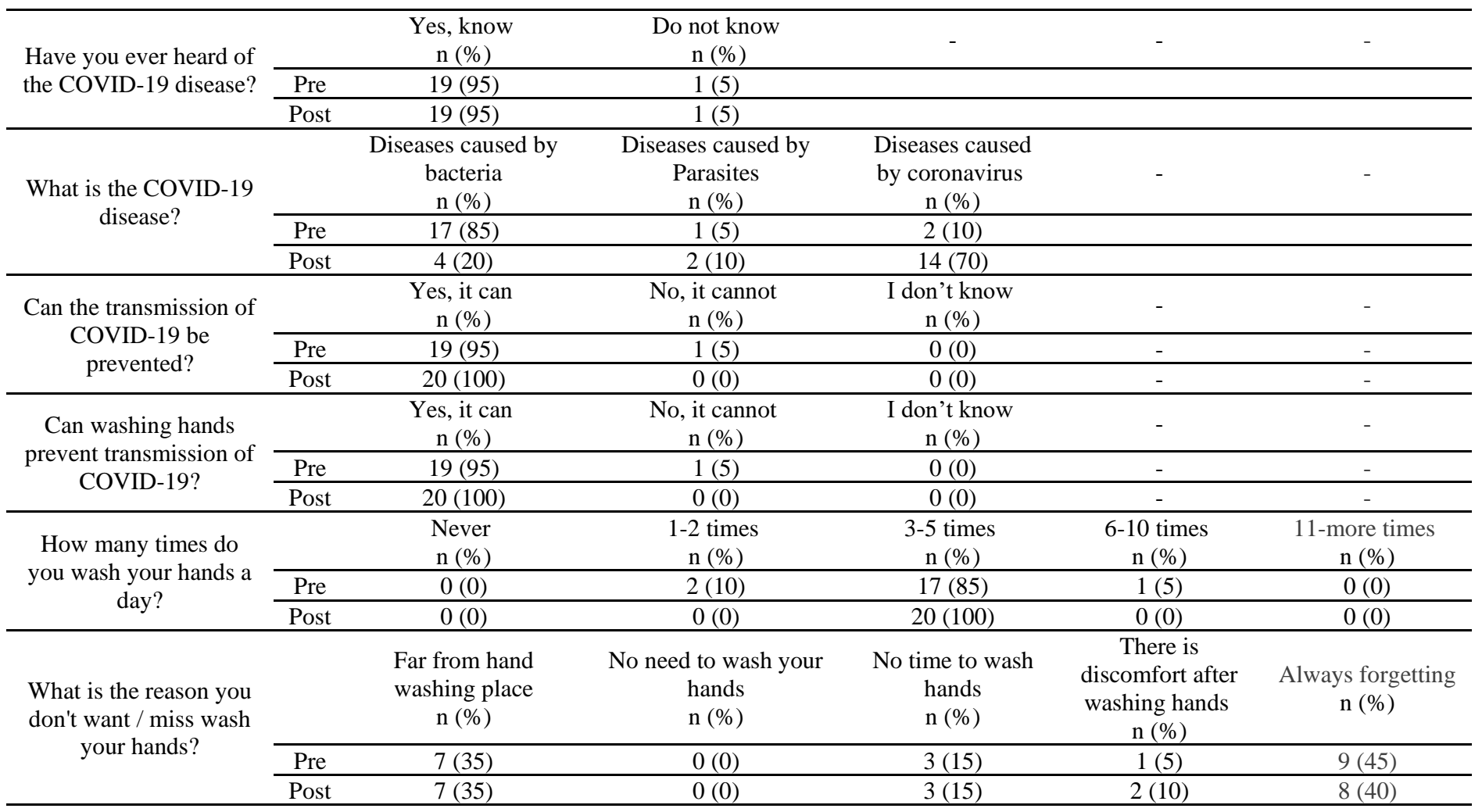

Table 3. Distribution of hand washing practice questionnaire results based on the TBP method at the Rodhiyatul Jannah Islamic Boarding School, Surabaya, East Java Province in September $2020(n=20)$.

\begin{tabular}{|l|c|c|c|c|}
\hline & & $\begin{array}{c}\text { Never } \\
\mathrm{n}(\%)\end{array}$ & $\begin{array}{c}\text { Sometimes } \\
\mathrm{n}(\%)\end{array}$ & $\begin{array}{c}\text { Always } \\
\mathrm{n}(\%)\end{array}$ \\
\hline \multirow{2}{*}{ I wash my hands before eating } & Pre & $0(0)$ & $1(5)$ & $19(95)$ \\
\hline \multirow{2}{*}{ I wash my hands after eating } & Post & $0(0)$ & $0(0)$ & $20(100)$ \\
\hline $\begin{array}{l}\text { I wash my hands before going to the toilet } \\
\text { (urinating / defecating) }\end{array}$ & Pre & $0(0)$ & $0(0)$ & $20(100)$ \\
\cline { 2 - 4 } & Post & $0(0)$ & $1(5)$ & $19(95)$ \\
\hline \multirow{2}{*}{ I wash my hands after urinating / defecating } & Pre & $0(0)$ & $4(20)$ & $16(80)$ \\
\hline \multirow{2}{*}{ I washed my hands after I got home } & Pre & $0(0)$ & $2(10)$ & $18(90)$ \\
\cline { 2 - 4 } & Post & $0(0)$ & $2(10)$ & $18(90)$ \\
\hline \multirow{2}{*}{$\begin{array}{l}\text { I wash my hands after shaking hands with } \\
\text { other people }\end{array}$} & Pre & $0(0)$ & $3(10)$ & $18(90)$ \\
\cline { 2 - 4 } & Post & $0(0)$ & $2(10)$ & $17(85)$ \\
\cline { 2 - 4 } & Pre & $1(5)$ & $7(35)$ & $12(60)$ \\
\hline
\end{tabular}




\begin{tabular}{|c|c|c|c|c|}
\hline \multirow{2}{*}{ I wash my hands before bed } & Pre & $3(15)$ & $11(55)$ & $6(30)$ \\
\hline & Post & $0(0)$ & $4(20)$ & $16(80)$ \\
\hline \multirow{2}{*}{$\begin{array}{l}\text { I wash my hands after using public } \\
\text { transportation }\end{array}$} & Pre & $3(15)$ & $8(40)$ & $9(45)$ \\
\hline & Post & $0(0)$ & $5(25)$ & $15(75)$ \\
\hline \multirow{2}{*}{$\begin{array}{l}\text { I wash my hands after waking up in the } \\
\text { morning }\end{array}$} & Pre & $3(15)$ & $2(10)$ & $15(75)$ \\
\hline & Post & $0(0)$ & $4(20)$ & $16(80)$ \\
\hline \multirow{2}{*}{$\begin{array}{l}\text { I wash my hands after playing / handling } \\
\text { animals }\end{array}$} & Pre & $1(5)$ & $8(40)$ & $11(55)$ \\
\hline & Post & $1(5)$ & $3(15)$ & $16(80)$ \\
\hline \multirow{2}{*}{ I wash my hands only when they are dirty } & Pre & $2(10)$ & $1(5)$ & $17(85)$ \\
\hline & Post & $1(5)$ & $2(10)$ & $17(85)$ \\
\hline \multirow{2}{*}{ I prepare my hands before preparing the food } & Pre & $3(15)$ & $5(25)$ & $12(60)$ \\
\hline & Post & $1(5)$ & $3(15)$ & $16(80)$ \\
\hline \multirow{2}{*}{ I wash my hands after handling Money } & Pre & $4(20)$ & $8(40)$ & $8(40)$ \\
\hline & Post & $2(10)$ & $8(40)$ & $10(50)$ \\
\hline \multirow{2}{*}{ I wash my hands after handling the trash } & Pre & $0(0)$ & $1(5)$ & $19(95)$ \\
\hline & Post & $0(0)$ & $0(0)$ & $20(100)$ \\
\hline \multirow{2}{*}{ I wash my hands before handling sick people } & Pre & $1(5)$ & $6(30)$ & $13(65)$ \\
\hline & Post & $1(5)$ & $6(30)$ & $13(65)$ \\
\hline \multirow{2}{*}{ I do hands after holding sick people } & Pre & $2(10)$ & $3(15)$ & $15(75)$ \\
\hline & Post & $1(5)$ & $3(15)$ & $16(80)$ \\
\hline \multirow{2}{*}{ I wash my hands after combing my hair } & Pre & $4(20)$ & $11(55)$ & $5(25)$ \\
\hline & Post & $3(15)$ & $8(40)$ & $9(45)$ \\
\hline \multirow{2}{*}{ I wash my hands after cleaning the house } & Pre & $2(10)$ & $3(15)$ & $15(75)$ \\
\hline & Post & $1(5)$ & $2(10)$ & $17(85)$ \\
\hline \multirow{2}{*}{ I wash my hands after washing dishes } & Pre & $1(5)$ & $1(5)$ & $18(90)$ \\
\hline & Post & $1(5)$ & $1(5)$ & $18(90)$ \\
\hline \multirow{2}{*}{ I wash my hands after washing clothes } & Pre & $0(0)$ & $5(25)$ & $15(75)$ \\
\hline & Post & $1(5)$ & $2(10)$ & $17(85)$ \\
\hline
\end{tabular}

Table 4. The results of statistical tests using the Paired T-Test to determine the effect of TBP education on the level of knowledge and practice of hand washing in school age children. at the Rodhiyatul Jannah Islamic Boarding School, Surabaya, East Java Province in September $2020(n=20)$.

\begin{tabular}{llll}
\hline Variables & Mean & Std. Deviation & Paired t test \\
\hline Hand washing knowledge & 0.30 & 0.47 & 0,010 \\
Practice washing your hands & 1.95 & 7.87 & 0.282 \\
\hline
\end{tabular}

Data related to knowledge of school children before education shows that most school children know about COVID-19 (95\%), do not know the cause of COVID$19(80 \%)$, know that transmission of COVID-19 can be prevented (95\%), know that washing hands can prevent transmission of COVID-19 (95\%), washing hands 3-5 times a day (85\%), and the reason for not washing hands is always forgetting (45\%). After education, most school children know about COVID-19 (95\%), know the cause of COVID-19 (70\%), know that transmission of COVID-19 can be prevented (100\%), know that washing hands can prevent transmission of COVID1919 (100\%), washing hands 3-5 times a day $(100 \%)$ (Table 2).

Table 3 showed that the hand washing behavior of school children before and after the TPB education was carried out on washing hands. These results indicate a 
change in the percentage from not or rarely doing hand washing after doing activities to always washing hands.

The results of the Paired-t test show that there is a significant effect of the TPB educational intervention on hand washing on knowledge of hand washing in the health education activities sample. This is evidenced by the value of $p=0.010 / p<$ 0.05 . Meanwhile, TPB education had no effect on the practice of hand washing behavior among schoolchildren $\mathrm{p}=0.282$ (Table 4).

The results of this health education activities indicate that there is a change in the knowledge of school children about hand washing. Hand washing behavior is an important indicator in TPB during the COVID-19 pandemic. This educational activity is only one of the stimulation activities to socialize correct hand washing behavior and according to recommendations.

The pre-test results show that most school children do not know the cause of COVID-19 (80\%). After education, most school children know about the causes of COVID-19 (70\%). School children also know the importance of washing hands to prevent transmission of COVID-19. There is a need for continuity in implementing policies from the school so that the habit of washing hands properly becomes a behavior that students can apply while in school. The sustainability of this activity is also very important, so that information can be continuously conveyed to students and it is hoped that it can become the basis for changing the behavior of students' hand washing at school. In the future, it is hoped that TPB education on proper hand washing habits can be socialized by the school to all students at all grade levels.
The results of this health education activities indicate that a small proportion of school-age children often wash their hands before eating and after defecating at home or school. If students do not have a good habit of washing their hands before eating and after using the toilet, their hands can become contaminated with the virus, and their friends can catch them while playing together. Previous research has shown that close contact between school-age children and poor hand hygiene practices is one of the main causes of the spread of infectious diseases in the school environment (Yuen, et al., 2020).

Hand washing behavior is shown through an attitude that shows a desire to wash hands properly. Thus, this study suggests an intervention program to formulate strategies that reinforce motivation to comply with these significant others, with the aim of strengthening students' attitudes towards and hand washing practices. An important new finding from this study is that teachers have a stronger influence on hand-washing behavior among school-age children, compared to family and peers, particularly students living in Islamic boarding schools. Teachers are not only responsible for imparting knowledge to students, but also guiding students' daily behavior, including hygiene habits (Graves, et al., 2014). Moreover, teachers are highly respected and trusted by elementary school students. Previous research has shown that adequate teacher support for students is the key to implementing and maintaining a hygiene and hand washing program among students (Sun, et al., 2019).

The results of the evaluation of this activity also provide important information for health practitioners, families, and educators to design educational programs 
and interventions to improve hand hygiene among students. Further health education activities are expected to be able to implement designs and validate handwashing behavior using direct observation methods. The findings from this activity can be used to develop interventions to promote adequate hand washing among school-age children.

It is important not only to evaluate hand-washing behavior, but also to evaluate whether interventions and hand washing do reduce the risk of spreading infectious diseases targeted at specific populations. This is recommended to be applied as an evaluation of the Transmission-Based Precaution (direct, droplet and air transmission)

\section{CONCLUSION}

Transmission-Based Precaution (TBP) education contributes to increasing knowledge of washing hands for school age children. However, education is not sufficient to promote better handwashing practices and skills adopted by school-age children. Further research is recommended to conduct comprehensive evaluations and interventions to improve student compliance in hand washing to prevent infectious diseases, especially Covid-19.

\section{REFERENCES}

Assefa, M., \& Kumie, A. (2014). Assessment of factors influencing hygiene behaviour among school children in Mereb-Leke District, Northern Ethiopia: a cross-sectional study. BMC Public Health, 14(1), 1000.

Centers for Disease Control and Prevention [CDC]. (2002). Guideline for hand hygiene in health-care settings. $M M W r, 51(16), 1-44$.
Chittleborough, C. R., Nicholson, A. L., Basker, E., Bell, S., \& Campbell, R. (2012). Factors influencing hand washing behaviour in primary schools: process evaluation within a randomized controlled trial. Health education research, 27(6), 10551068.

Contzen, N. \& Mosler, H. J. (2015). Identifying the psychological determinants of handwashing: Results from two cross-sectional questionnaire studies in Haiti and Ethiopia. Am. J. Infect. Control, 43, 826-832.

Dickie, R., Rasmussen, S., Cain, R., Williams, L., \& MacKay, W. (2018). The effects of perceived social norms on handwashing behaviour in students. Psychology, health \& medicine, 23(2), 154-159.

Graves, J. M., Finsness, E. D., Quick, R., Nyando Integrated Child Health and Education Project (NICHE) Study Team, Harris, J. R., \& Daniell, W. E. (2014). Teacher perspectives on implementing and sustaining a handwashing promotion intervention in Western Kenyan primary schools. International Quarterly of Community Health Education, 34(2), 159-170.

Haas, J. P. (2016). Handwashing and nail clipping reduce risk of intestinal parasite infection in school-age children. Evidence-based nursing, 19(2), 49-49.

Hirai, M., Graham, J. P., Mattson, K. D., Kelsey, A., Mukherji, S., \& Cronin, A. A. (2016). Exploring determinants of handwashing with soap in Indonesia: a quantitative analysis. International journal of environmental research and public health, 13(9), 868.

Kratzel, A., Todt, D., V'kovski, P., Steiner, S., Gultom, M., Thao, T.T.N., Ebert, N., Holwerda, M., Steinmann, J., Niemeyer, D. and Dijkman, R. (2020). Inactivation of 
severe acute respiratory syndrome coronavirus 2 by WHOrecommended hand rub formulations and alcohols. Emerging infectious diseases, 26(7), $1592 . \quad$ Doi: https://doi.org/10.3201/eid2607.20 0915.

Lapinski, M. K., Maloney, E. K., Braz, M., \& Shulman, H. C. (2013). Testing the effects of social norms and behavioral privacy on hand washing: A field experiment. Human Communication Research, 39(1), 21-46.

Mahmud, M. A., Spigt, M., Bezabih, A. M., Pavon, I. L., Dinant, G. J., \& Velasco, R. B. (2015). Efficacy of handwashing with soap and nail clipping on intestinal parasitic infections in school-aged children: a factorial cluster randomized controlled trial. PLoS Med, 12(6), e1001837.

Sun, C., Wang, Q., Poudel Adhikari, S., Ye, R., Meng, S., Wu, Y., Mao, Y., Raat, H. and Zhou, H. (2019). Correlates of School Children's Handwashing: A Study in Tibetan Primary Schools. International journal of environmental research and public health, 16(17), 3217.

Yuen, K. S., Ye, Z. W., Fung, S. Y., Chan, C. P., \& Jin, D. Y. (2020). SARSCoV-2 and COVID-19: The most important research questions. Cell \& bioscience, 10(1), 1-5. 